\title{
CASE REPORT \\ ELECTRICAL STIMULATION OF THE CONUS MEDULLARIS FOR BLADDER EMPTYING IN A PARAPLEGIC
}

\author{
By Carl-Axel Carlsson, M.D., ${ }^{1}$ and Magnus Fall, M.D. ${ }^{2}$ \\ ${ }^{1}$ Departments of Neurosurgery and ${ }^{2}$ Urology, Sahlgrenska Hospital, Göteborg, Sweden
}

Summary. Nashold et al. (1972) have developed a surgically implantable system for activating the micturition reflex in the paraplegic by electrical stimulation of the spinal cord at the conus level. This communication describes the longterm course in a paraplegic patient who has used conus stimulation to achieve bladder emptying for 7 years.

A 42-year-old man sustained a complete transverse lesion at the C6 level. Ten months after the accident he developed some spasticity in his legs but his urinary bladder remained completely flaccid. A device for electrical stimulation of the conus was implanted. This enabled the patient to empty his bladder without significant residual urine. His bladder remained flaccid. Seven years after the implant he developed reflex micturition and he is no longer dependent upon electrical stimulation.

Key words: Paraplegia; urinary bladder areflexia; electrical stimulation.

\section{Case Report}

The PATIENT, a 42-year-old male, sustained a complete transverse lesion at the C6 level after a fall from a trapeze in July I975. He was initially treated with skeletal traction. His lesion remained complete. Four months after the accident, he developed some spasticity in the legs but his urinary bladder was completely flaccid. Cystometry during the autumn of 1975 and the spring of 1976 showed no detrusor contractions during bladder filling and there was no detrusor response to external stimulation. Ten months after the accident, the bladder was still flaccid but the ice-water test had become positive, indicating a preserved reflex pathway between the bladder and the sacral spinal cord. Sphincterotomy was performed but the patient could still not empty his bladder. Because of his neurological deficit, he could not manage self-catherisation. In this situation, conus stimulation, according to Nashold, was considered to be an appropriate procedure.

The permanent device consists of $2.5 \mathrm{~mm}$ insulated platinum electrode pins with $0.5 \mathrm{~mm}$ bare tips, mounted $2.5 \mathrm{~mm}$ apart on a holder and connected to a radio receiver activated by an external radio frequency transmitter. An alternate pulse signal is delivered to the electrodes. The frequency, pulse width and stimulation voltage can be varied. The whole equipment is commercially available from Avery Laboratories, Inc.

Before the permanent implantation, test stimulation was performed by means of two electrodes inserted percutaneously and placed anteriorly and posteriorly to the conus region. Stimulation via these electrodes resulted in a bladder contraction. This was considered to prove that conus stimulation would be successful. 
Operative procedure

Permanent implantation of the conus stimulator was performed in May 1976. Prior to the operation, the bladder was filled with $500 \mathrm{ml}$ of Ringer solution and the intravesical pressure was continuously monitored during the operation. The dorsal surface of the conus was exposed and a bipolar stimulating probe was used to locate the site which gave the most pronounced intravesical pressure rise. The permanent electrodes were inserted at this site, gently secured by means of a strip around the conus and connected to the subcutaneously implanted radio receiver.

\section{Post-operative course}

Two days post-operatively, the bladder was filled with $500 \mathrm{ml}$ of Ringer solution. The catheter was withdrawn and on stimulation the patient voided $250 \mathrm{ml}$. Urethral pressure profiles with and without stimulation showed a small area giving a marked increase of urethral pressure during stimulation. This area corresponded to the distal part of the external sphincter and another small sphincterotomy was performed at this site. Stimulation now resulted in better emptying of the bladder, with only $50 \mathrm{ml}$ of residual urine. Figure I illustrates the effect on bladder and urethral pressures during step by step increase of the stimulation strength. It appears that the urethral structures respond at a lower threshold of stimulation than the bladder. The urethral response fades in spite of continued stimulation, possibly due to muscle fatigue. With increasing stimulation strength, the urethra contracts again, with subsequent fading. When the bladder contracts, the bladder neck opens and the intravesical and urethral pressures become equalised. This means that the closing pressure is zero and voiding occurs during a sustained detrusor contraction, although with a residual urine of $50 \mathrm{ml}$. The patient could further reduce his residual urine by repeating this procedure. In this way, he could empty his bladder almost completely by three sequences of stimulation.

The emptying of the bladder has been studied by means of micturition cystourethrography. The micturition starts with a symmetrical contraction of the bladder and a synchronised widening of the proximal urethra (Fig. 2). When the bladder is emptied a small volume of contrast remains

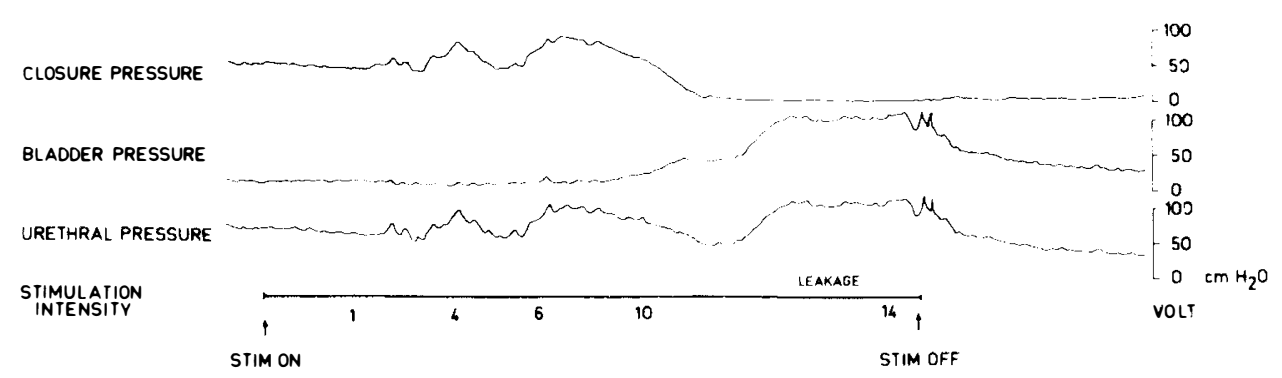

FIG. I

The urethral and bladder pressures during step-by-step increase of the stimulation strength. Closure pressure $=$ bladder pressure minus urethral pressure. 


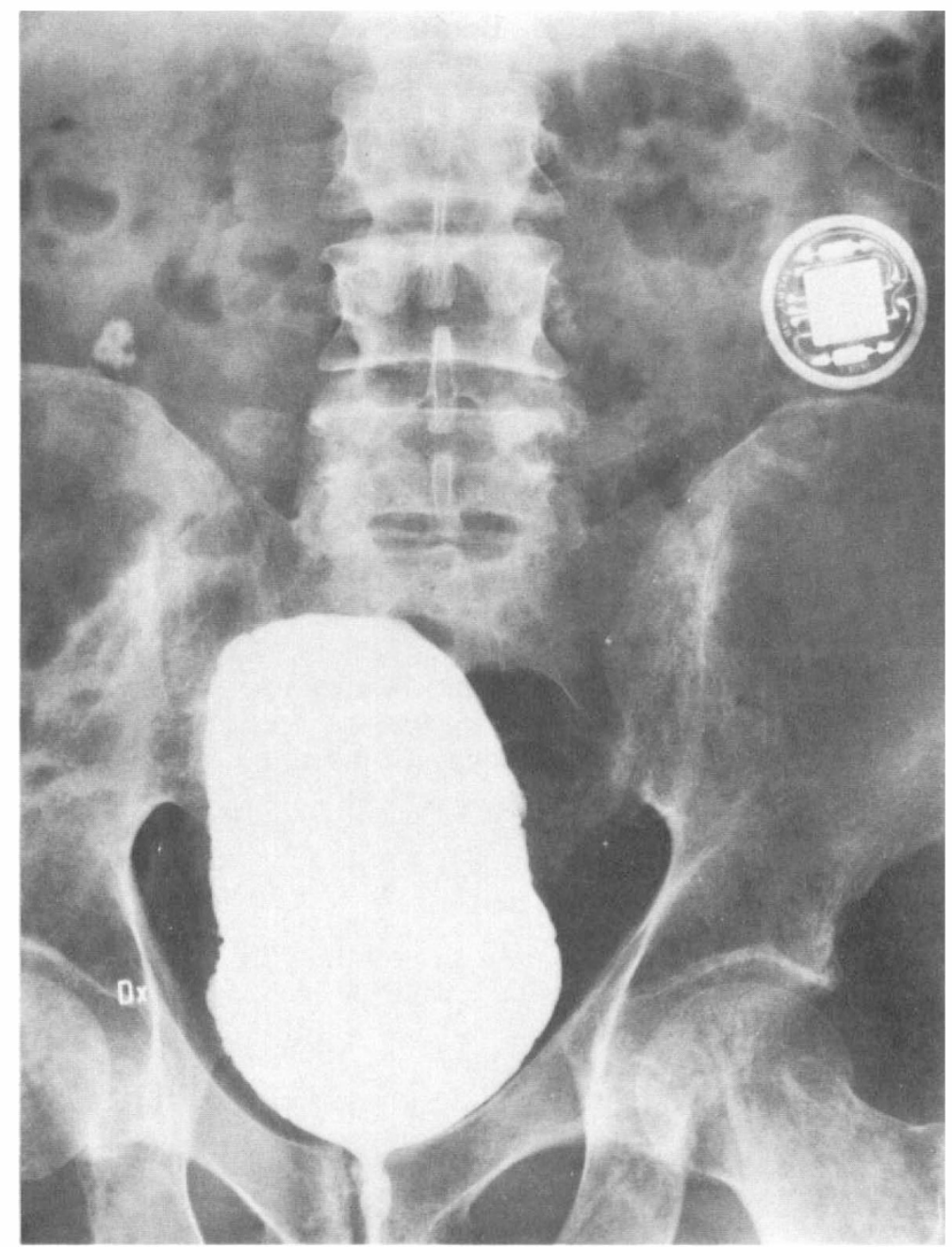

FIG. 2

Symmetrical bladder contraction with opening of the proximal urethra at the start of stimulation. The implanted receiver in the right upper corner.

in the urethra. When stimulation stops, this small volume runs back into the bladder, which explains the residual urine of approximately is $\mathrm{ml}$. During the first few weeks post-operatively, the patient's blood pressure increased up to $200 \mathrm{mmHg}$ on stimulation. This effect could be eliminated by giving a beta-blocker (Inderal), which was withdrawn after two weeks. At this stage, stimulation caused no blood-pressure rise. During stimulation there were tonic movements of the lower limbs. It was found that this effect could be reduced by changing the stimulation parameters. Thus, a frequency of $33 \mathrm{~Hz}$ was most appropriate, and if the stimulation strength was increased slowly it was found that the output voltage required for bladder contraction was generally lower than that pro- 
ducing motor activity in the limbs. Because of his neurological deficit, the patient could not regulate the stimulation strength by means of the control knob. The optimum stimulation parameters were therefore preset. He then slowly moved the antenna towards the receiver and could in this way slowly increase the stimulation up to the present level.

\section{Long-term course}

The stimulation equipment has now functioned successfully for 7 years since implantation. The patient has had periodic bacteruria but not upper urinary tract complications. He has no catheter, can empty his bladder without significant residual urine and has normal IVPs. He has been followed up by regular cystometry. Two years after the implantation, there were weak signs of reflex bladder activity although not sufficient for bladder emptying. Four years after the implantation, the stimulation intensity had to be increased $\mathrm{I}-2 \mathrm{~V}$ to accomplish complete voiding. The situation has remained unchanged during the following years, but in I 982-7 years after the implantation the situation changed dramatically and he showed a fully developed micturition reflex on the cystometrogram. This means that he is now able to empty his bladder by external stimulation and his electrical stimulation equipment is no longer necessary for bladder emptying.

\section{Comments}

Persistent bladder areflexia is very uncommon following a complete cervical lesion. In such rare cases, manual self-catheterisation being impossible, the Nashold method is applicable and preferable to an indwelling catheter or suprapubic catheter.

The device is easy to handle. The patient empties his bladder 2-3 times daily and is far less handicapped than when having an indwelling catheter.

Extensive sphincterotomy and condom treatment has been advocated in patients with neuropathic bladders but it is doubtful whether this procedure would be adequate in a patient with an acontractile bladder and without any possibility of increasing the intraabdominal pressure by straining. Our patient certainly had to wear a condom since leakage could occasionally be induced by strong movements. This has been a minor problem, however, and he has emptied his bladder at convenient times, which is of importance to him because of his very active life.

Obviously, the long-term stimulation did not damage the conus area, as evidenced by the return of the micturition reflex 7 years after implantation. The late return of the micturition reflex is remarkable in itself. It means that synaptic reorganisation in the isolated spinal cord segment took place 7 years after a transverse lesion. A question which cannot be answered is whether the implantation of the conus stimulator and the stimulation have delayed the return of the micturition reflex or whether the stimulation has possibly created conditions for its return.

Indeed, the persistency of a flaccid, areflexic bladder is unusual following spinal cord lesions with a preserved conus area. According to 
our experience from this patient the Nashold method of conus stimulation can be recommended in such rare cases.

\section{RÉSUMÉ}

Nashold et coll. (1972) ont développé un système d'implantation chirugicale pour l'activation du réflexe micturitionel dans les cas de la paraplégie par stimulation électrique de la moelle épinière au niveau du cône. Cet article nous présente le cours de longue durée d'un malade paraplégique, qui a utilisé las stimulation du cóne pour atteindre le vidange de la vessie pendant sept ans.

Un homme de 42 ans fut atteint d'une lésion transverse au niveau C6. Dix mois après l'accident, le malade avait développé une certaine spasticité des membres inférieurs, mais la vessie demeurait complètement flacide. Un appareil permettant la stimulation électrique du cône fut implanté, permettant ainsi au malade de vider lui-même sa vessie pratiquement sans urine résiduelle. Sa vessie demeurait flacide. Sept ans après l'implantation le malade développa un réflexe micturitionel el il n'a plus besoin de la stimulation électrique.

\section{ZUSAMMENFASSUNG}

Nashold und Mitarbeiter (1972) haven zur Aktivierung des Miktions-reflexes bei querschnittsgelähmten Patienten durch electrische Stimulation des Rückenmarkes im Conusbereich ein durch Chirurgie einpflanzbares System entwickelt. Diese Mitteilung beschreibt den Langzeitsverlauf eines paraplegischen Patientens, der zur Blasenentleerung Conusstimulation über sieben Jahre gebraucht hat.

Ein 42-jähriger Mann erhielt eine totale Rückenmarksläsion im Bereich $\mathrm{C}_{6}$. Zehn Monate nach dem Unfall entwickelte sich eine gewisse Spastizität der Beine, aber seine Harnblase verblieb schaff. Eine Dauervorrichtung zur electrischen Conusstimulation wurde implantiert. Diese gestattete dem Patienten, seine Blase ohne signifikanten Restharn zu entleeren. Die Blase verblieb jahrelang atonisch. Sieben Jahre nach der Einpflanzung entwickelte er eine sogenannte Reflexmiktion und er ist jetzt imstande ohne elektrischen Reiz seine Blase zu entleeren.

\section{REFERENCES}

Nashold, B. S., Jr., H. Friedman, J. F. GlenN, J. H. Grimes, W. F., Barry \& Avery, R. (1972). Electromicturition in paraplegia. Arch Surg., 104, 195-202. 